\title{
THE COMPARISON OF APPLICATION OF STOCK RETURN EVALUATION IN RECORDED COMPANIES IN LQ 45 FOR THE 2012-2016 PERIOD
}

\author{
Neneng Susanti ${ }^{1}$, Deden Novan Setiawan Nugraha ${ }^{2}$ \\ 1,2 Faculty of Business and Management, Widyatama University \\ ${ }^{1}$ neneng.susanti@widyatama.ac.id \\ ${ }^{2}$ deden.novan@widyatama.ac.id
}

\begin{abstract}
The purpose of this study is not only to compare the Capital Asset Price Model, Arbitration Price Theory, Three Factor Price Model, Three Factor Price Model, and Five Factor Price Model to study the Capital Asset Price Model, Price Arbitration Price Theory, Three Factor Price Model, Four Factors Pricing Model and Five Factors Pricing Model for excess returns and for determining the best asset pricing model in terms of the ability to explain estimates of excess returns. This research includes explanatory research (explanatory research), namely looking at the relationship between research variables and testing hypotheses that have been formulated previously. This study examines the effect of variables in the asset pricing model and compares the asset pricing models in explaining excess returns. Based on the results of the research that has been carried out the best model that can be used in assessing the asset pricing model is the five Price Model Factors, this is evidenced by the value of R2 or R Square of $89.4 \%$, the value is greater than the value of R2 or R Square Capital Asset Pricing Model, Arbitration Price Theory, Three Price Factor Models, and Four Price Factor Models, which were $34.7 \%, 55.2 \%, 77.2 \%$ and $79 \%$ respectively.
\end{abstract}

Keywords: Asset Pricing Model (CAPM), Arbitration Pricing Determination Theory (APT), Three Factor Model, Carhart Model four factors, and Five Factor Price Model.

\section{Introduction}

Economic growth is one of the important goals of macroeconomic policies that will be able to provide welfare to the community. One measure of community welfare is the level of income per capita. Indonesia is currently in an economic condition supported by a strong domestic market. According to Maryaningsih, (2014) states that the improvement of infrastructure conditions both hard and soft need to be pursued by considering geographical aspects and regional needs, with improvements in infrastructure conditions that will facilitate the mobility of people and goods, thereby increasing economic productivity.

The results of research conducted by Fauziyah (2013) show that the variable economic growth has a positive effect on the growth of the Indonesian stock exchange. The Index Growths of IDX and Leading World Bourses shows that the Indonesian capital market is progressing. It is known that during the period of 2006 to 2016 the IDX recorded a market index growth of $194 \%$, the highest among the world's major exchanges. The Indonesia Stock Exchange (IDX) recorded the highest growth in 2016 during the study period, besides that the Indonesia Stock Exchange also recorded several records on almost all indicators of daily trading. This reflects a more active market in line with the increasing number of investors entering the capital market. Indonesia's capital market performance in 2016 was recorded as one of the best in the world. At the end of 2016, Indonesia's capital market was ranked second best in AsiaPacific and the 4th best in the world, several factors such as strengthening the rupiah exchange rate against the US dollar, improving the domestic economy, 
restoring the credibility of the APBN, and implementing the Tax Amnesty the good one. (www.idx.co.id).

This good capital market performance is also reflected in the Composite Stock Price Index (CSPI) reaching 6.05 percent. CSPI in the past 5 years was also able to record a good performance with a return reaching 27.14 percent. CSPI, which tends to move positively, certainly influences the performance of equity funds, which allocate the majority of its assets to stock instruments. Investors certainly expect profits when conducting an investment activity. The expected profit comes from how much the return will be obtained optimally. But in some cases there is a difference between the return received by the investor (actual return) and the expected rate of return. This situation shows that in carrying out an investment activity, investors will face risks. Fahmi (2013) states that in financial theory the risk of an investment increases, investors will require a higher expected return. When an investor conducts an investment activity there are at least three basic factors in making investment decisions which consist of the rate of return (risk), risk that will be faced (Risk), and the time factor.

In this study selected groups of stocks included in the LQ45. This index consists of 45 companies whose shares have high liquidity. Based on listed stocks in LQ45 after being re-selected according to the established criteria, showing that of the 45 companies listed in LQ45 in a row from 2012-2016 20 companies were selected. Although shares in LQ45 are included in the category of superior stocks, it is found that the majority of shares produce negative returns in a row. In the investment portfolio there is a model that is often used by investors in predicting the expected return, the Capital Asset Pricing Model (CAPM) introduced by Sharpe, Lintner, and Mossin in the mid-1960s. In 1976 Ross proposed a new model in calculating stock returns, namely Arbitrage Pricing
Theory (APT). This theory explains the relationship between expected returns from a security, assuming there is no opportunity to generate profits from arbitration investments without risk. Susanti (2013) states that there are three assumptions that underlie the Arbitrage Pricing Theory (APT) model is that capital markets are in perfect competitive conditions, investors always prefer a high return value rather than a high risk that causes uncertainty of return.

In 1992, Eugene Fama and Kenneth French made a study whose results have been very influential to date, namely in the determination of asset prices and portfolio management using a threefactor model to describe stock returns. The three factors are market return, firm size, and book to market company. The development of the Asset Pricing theory continues to be carried out until Carhart (1997) adds the momentum factor WML (Winner Minus Loser) to three factors that are on the Fama-French Three Factor Model. Furthermore in 2014, Eugene Fama and Kenneth French perfected their findings in 1992 by adding profitability and investment factors.

Darusman (2012) research of stocks with high book to market (HML) has a relatively higher risk than stocks with lower book to market ratio (HML) so investors will expect a higher return on stocks that have a book to market ratio (HML) is high. While the LQ 45 index of companies that are in a high book to market ratio (HML) actually has a lower return. Lemiyana (2015) found that CAPM and APT have little effect on return. Isnurhadi (2014) about the analysis of the CAPM model in predicting the level of sharia and conventional stock returns also shows that the CAPM has a small effect on return. The research conducted by Irsad, et al. (2012) in LQ 45 shares in the period 2007-2009 stated that the risk premium has a positive and significant effect on stock returns. Susanti, (2013) research conducted on LQ 45 shares in the period 
2005-2009 stated that all three factors of fama French variables had a positive and significant effect on excess return.

Seeing the uncertainty in the results of previous research conducted and the continuous development of the theory of Asset Pricing, the research in this theory is very interesting to do and get results in supporting the existing theory. Based on the background described, the author is interested in conducting a research entitled "Comparison of Application of Stock Return Assessment in Companies that are recorded in the 2012-2016 LQ $45 "$.

\section{Theoretical Framework}

\subsection{Stock}

According to Darmadji and Fakhruddin (2012: 5), shares can be defined as a sign of inclusion or ownership of a person or entity in a company or limited liability company (PT). While Tandelilin (2010: 243) explained that stocks are proof that ownership of the assets of companies that issue shares. According to Bodie et. al. (2014: 42), shares are part of ownership in a company.

\subsection{Return}

Fahmi (2012: 189), states that returns are profits obtained by companies, individuals and institutions from the results of investment policies that they do. Jogiyanto (2015: 205) explained that returns are the results obtained from investments. Return can be a realized return that has occurred which is calculated based on historical data and expected return that has not occurred, but which is expected to occur in the future. Based on some of these opinions, the return is basically the expected rate of return on investment activities that have been carried out. Legiman (2015) argues that stock returns are the results obtained from investment. A financial asset shows the willingness of an investor to provide a certain amount of funds at this time to obtain a flow of funds in the future as compensation for the time factor as long as the funds are invested and the risks borne.

\subsection{Capital Asset Pricing Model (CAPM)} The CAPM model was introduced by Treynor, Sharpe and Litner. The CAPM model is the development of portfolio theory presented by Markowitz by introducing new terms namely systematic risk and unsystematic risk. Understanding Capital Asset Pricing Model (CAPM) is a risk-pricing model of securities (assets) in the market balance in a well-diversified portfolio.

Capital Asset Pricing Model (CAPM) states in an equilibrium state, the market portfolio is tangential from the average portfolio variance. Capital Asset Pricing Model (CAPM) implies that the risk premium of any individual asset or portfolio is the product of premium risk in the market portfolio and beta coefficient. According to the theory of Capital Asset Pricing Model (CAPM) the level of income expected from a security can be calculated using the formula:

$$
E(\mathbf{R i})=\mathbf{R F}+\boldsymbol{\beta i}[\mathbf{E}(\mathbf{R M})-\mathbf{R F}]
$$

\section{$\mathrm{E}(\mathrm{Ri})=$ Expected level of income from securities $\mathrm{i}$.} $\mathrm{RF} \quad=$ Risk free income level.

$\mathrm{E}(\mathrm{RM})=$ The level of income expected from the market portfolio. $\beta \mathrm{i}=$ Risk measure that cannot be diversified from securities $\mathrm{i}$

\subsection{Arbitration Pricing Theory (APT)} Arbitration Pricing Theory (APT) is another model besides being ready to assess a financial asset. The arbitration price formation theory or what is often referred to as arbitration pricing theory was formulated in 1976 by Stephen Ross. (Chandra 2014: 18) state that in the Arbitration Pricing Theory (APT) model securities returns is not only influenced 
by market portfolios because of the assumption that the expectations of a security can be influenced by several other sources of risk. The macroeconomic variables used in this study are inflation, exchange rates, Bank Indonesia interest rates (SBI), money supply (JUB), and gross domestic product (GDP). The Arbitration Pricing Theory (APT) model can be formulated with the basic principle of believing that day and securities will be determined by a factorial model with risk factors, the suggested APT model is as follows (Lemiyana, 2015).

$$
\mathrm{E}(\mathrm{Ri})=\mathrm{a} 0+\mathrm{bi1F} 1+\mathrm{bi2} 2 \mathrm{~F}+\ldots+\mathrm{binFn}
$$

E (Ri) : Return Expectations of securities i

a0 : Return expectations of securities if the systematic risk is 0

bin : Coefficient which indicates the magnitude of the influence of factors on security Returns i

F : Risk premium for a factor

\subsection{Three Factors Pricing Model}

The Three Factors Pricing Model introduced by Fama and French (1993) becomes an alternative model in estimating expectations. Doubts and pros and cons of the accuracy of market beta is the only explanatory variable. If in the CAPM the return and risk behavior is only determined by the market, Fama and French add the company's fundamental factors, namely firm size and book to market. Thus, the three explanatory variables in the estimation of expected returns include premium market, premium size, and book to market premium. Monthly returns are regressed to premium market, premium size, and book to market premium formulated in the following equation:

\section{$E(R i)=R f+b i[E(R m)-R f]+\operatorname{siE}(S M B)+h i E(H M L)+e$}

E (Ri) : Theexpected stock return i

$\mathrm{Rf} \quad$ : The risk free rate asset

$\mathrm{E}(\mathrm{Rm})$ : The rate of return on market

SMB : The difference in value portfolio of small stock weighted return and value weighted return portfolio of large capitalized shares

HML : The difference in value weighted return on stock portfolios with high book to market and low value-weighted return book to market stock portfolio.

$b_{i}, s_{i}, h i$ : regression slope

Fama and French added factor size and book to market to complement the role of market beta coefficients in the CAPM described in the previous section.

\subsection{Four Factors Pricing Model}

The model developed by Fama-French is considered to have the ability to explain anomaly more than the CAPM model. However, these three factors have not been able to explain the short term reversal pattern. Jagadesh and Titman
(1993) found what is known as momentum strategy. Rowenhorst (1998) tested the effect of momentum and firm size effects on 12 countries in Europe using the same method as Jagdesh and Titman (1993) who said the phenomenon of momentum exists without coincidence.

The four-factor model used in evaluating funding work begins with Carhart (1997), the momentum found in Jagedesh 
and Titman (1993) describes portfolio performance in the literature model. Carhart added the momentum factor
WML (Winner Minus Loser) in the Fama-French Three Factor Model.

$$
\operatorname{Ri}(t)-\operatorname{Rf}(t)=a i+\beta i[R m(t)-R f(t)]+\text { si SMB (t) + hi HML (t) + wi WML (t) + e (t) }
$$

The four factors proposed in this model as variables that influence portfolio returns are book to market equity and company size (size), in this model there are HML (High Minus Low) and SMB (Small Minus Big) factors obtained and grouping stock returns shares that have high book to market (H), while (M) and low (L) and grouping of stock returns that have small (S) and large (B) company sizes and added WML (Winner Minus Looser), which is the momentum factor the difference between the return of outstanding winners and losers. Stock rate based on past returns.

\subsection{Five Factors Pricing Model}

The results of Fama and French (2014) show that the HML factor value is excessive to describe the average return when profitability and investment factors have been added in the equation. Fama and the French Five-Factors Asset Pricing Model explain between $71 \%$ and $94 \%$ of the expected variance. It has been proven that Fama and the French FiveFactors Asset Pricing Model are directed at capturing patterns of company size, book to market, profitability, and investment in stock returns providing a better explanation. This new model shows that the returning the highest expectations achieved by companies with little benefit and company value with growth prospects (Fama and French, 2014). In this study, Fama and French recommended using profitability and investment factors, in addition to existing factors (market risk, company size and book to market) to capture patterns in average stock returns.

\section{Methodology}

The type of data used in this study are all secondary data, namely published data such as Indonesia Capital Market Directory (ICMD), the Annual Report uploaded from the site www.idx.co.id and other sites related to data such as www.finance yahoo.com, www.sahamok.com, www.bi.go.id. The research method used in this study is explanatory research methods. In this study the method was used to answer the problems regarding the effect of the Capital Asset Pricing Model (CAPM), Arbitration Pricing Theory (APT), FamaFrench Three Factors Model, Four Factor Model, and Fama-French Five Factors Model on excess return on shares. Of the 45 companies listed in LQ45 in a row from 2012 to 2016, 20 companies were chosen as research samples. In this case the dependent variable related to the problem to be examined is excess return. While the independent variables related to the problems to be examined are market risk, inflation, exchange rate, SBI, JUB, GDP, market return, small minus big (SMB), high minus low (HML), Winner minus Low (WML), Robust Minus Weak (RMW) and Minus Aggressive Conservative (CMA). 


\section{Result and Discussion}

\subsection{Result}

4.1.1 CAPM Model Test (R2 or R Square)

Table 1. CAPM Model Test Results (R2 or R Square)

\begin{tabular}{|c|c|c|c|c|c|c|c|c|c|}
\hline \multicolumn{10}{|c|}{ Model Summary } \\
\hline & & & & & & Change Stati & tics & & \\
\hline Model & $\mathrm{R}$ & R Square & $\begin{array}{l}\text { Adjusted R } \\
\text { Square }\end{array}$ & $\begin{array}{l}\text { Std. Error of the } \\
\text { Estimate }\end{array}$ & R Square Change & F Change & $\begin{array}{c}\mathrm{df} \\
1\end{array}$ & df2 & $\begin{array}{l}\text { Sig. F } \\
\text { Change }\end{array}$ \\
\hline 1 & $.589^{\mathrm{a}}$ & .347 & .311 & .00772413 & .347 & 9.571 & 1 & 18 & .000 \\
\hline
\end{tabular}

The coefficient of determination essentially measures how far the ability of the regression model to explain the effect of variations in the dependent and independent variables. Based on the test results it is known that the relationship between excess return and beta shows a positive pattern of relationships, meaning that the higher the excess return obtained, the higher the risk (beta) that will be experienced by investors. The value of $\mathrm{R}$ Square based on the test results is $34.7 \%$, meaning that variable beta in explaining the variation of excess return is $34.7 \%$ while the rest is influenced by other factors outside the research model.

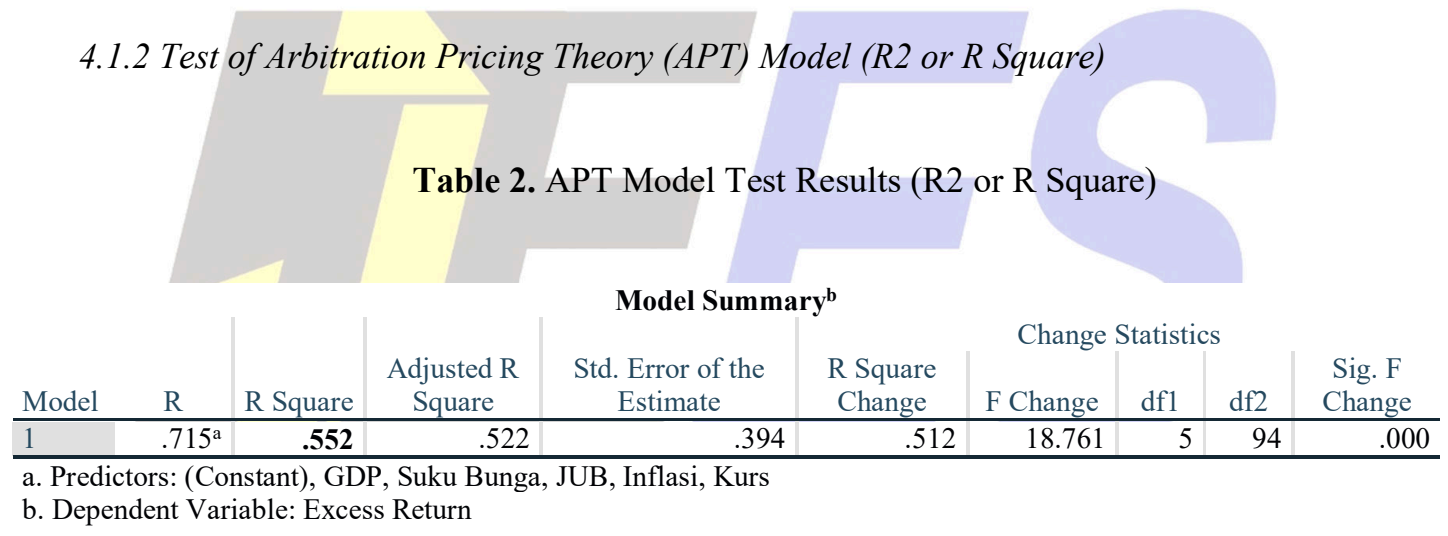

Inflation variable (X1), currency exchange rate (X2), Bank Indonesia interest rate (X3), money supply (X4), and gross domestic product (X5) explain the variation of excess return of 55.2 percent and the remainder is determined by variables others outside the research model. That is, Inflation, currency exchange rates, Bank Indonesia interest rates, the amount of money struggling, gross domestic product have a joint effect on excess return. The amount of influence is $55.2 \%$ while the rest is influenced by other variables outside of this study. This shows that investors can use inflation values, currency exchange rates, Bank Indonesia interest rates, money supply, gross domestic product as an indicator to consider stock returns that can be used as a basis for making decisions to invest. 


\subsubsection{Three Factors Model Test (R2 or R Square)}

Table 3. Three Factors Model Test Results (R2 or R Square)

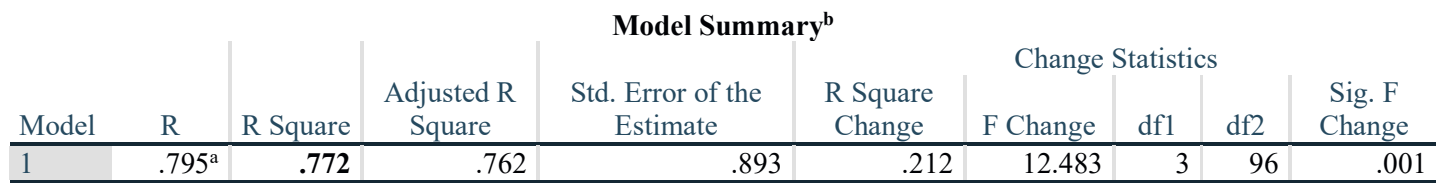

a. Predictors: (Constant), Market Return, SMB, HML

b. Dependent Variable: Excess Return

It is known that the market return $\left(\mathrm{X}_{1}\right)$, small minus big (SMB) $\left(\mathrm{X}_{2}\right)$, and high minus low (HML) (X3) variables, explain the variation of Excess Return (Y) of 77 percent, the remaining 23 percent is determined by other variables outside the model. In other terms it means that four explanatory variables chosen by the researcher can explain the variation of $\mathrm{Y}$ variable in a large sample.

\subsubsection{Four Factors Carhart Model Test (R2 or R Square)}

Table 4. Four Factors Carhart Model Test Results (R2 or R Square)

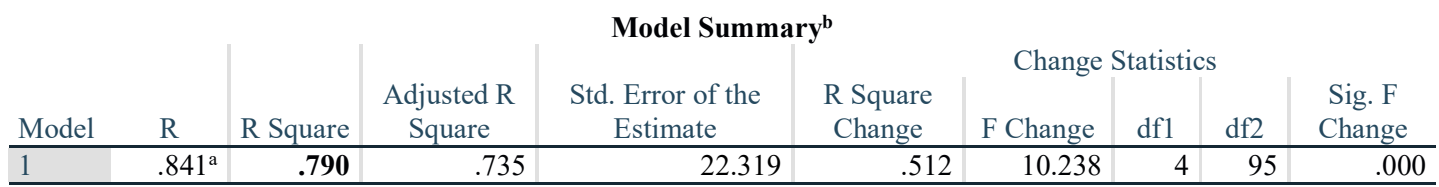

a. Predictors: (Constant), Market Return, SMB, HML, WML

b. Dependent Variable: Excess Return

It is known that the variable market return $\left(\mathrm{X}_{1}\right)$, small minus big $(\mathrm{SMB})\left(\mathrm{X}_{2}\right)$, high minus low (HML) (X3), and Winner minus Low (WML) (X4) explain the variation of Excess Return (Y) of 79 percent, the remaining 21 percent is determined by other variables outside the model. In other terms it means that four explanatory variables chosen by the researcher can explain the variation of $\mathrm{Y}$ variable in a large sample.

\subsubsection{Test the Fama \& French Five Factors Model (R2 or R Square)}

Table 5. Results of the Fama-French Five Factors Model Test (R2 or R Square)

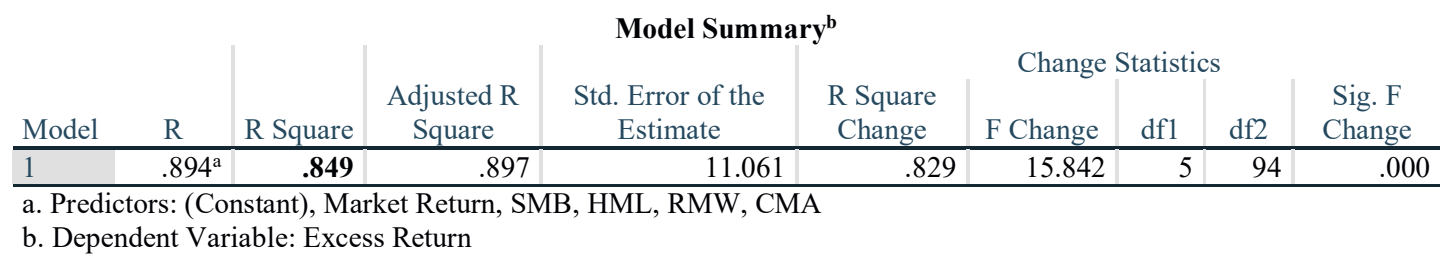

It is known that the market return variable $\left(\mathrm{X}_{1}\right)$, small big minus (SMB) $\left(\mathrm{X}_{2}\right)$, high minus low (HML) (X3), Robust Minus Weak (RMW) (X4) and Minus Aggressive Conservative (CMA) (X5) Excess Return (Y) of 84.9 percent, the remaining 15.1 percent is determined by other variables outside the model. In other terms it means that the five explanatory variables chosen by researchers can explain the variation of variable $\mathrm{Y}$. 


\subsubsection{Asset Pricing Model Test (One Way ANOVA Test)}

Table 6. One Way ANOVA Test Results

\begin{tabular}{|c|c|c|c|c|c|}
\hline \multirow{2}{*}{ ExcessReturn } & \multicolumn{3}{|c|}{ ANOVA } & \multirow[b]{2}{*}{$\mathrm{F}$} & \multirow[b]{2}{*}{ Sig. } \\
\hline & Sum of Squares & $\mathrm{df}$ & Mean Square & & \\
\hline Between Groups & 180.390 & 4 & 36.078 & 65.812 & .000 \\
\hline Within Groups & 13.157 & 15 & .548 & & \\
\hline Total & 193.547 & 19 & & & \\
\hline
\end{tabular}

Based on the One Way ANOVA Test results obtained where the probability value $(p)=0,000$ or value $(p)<0.05$ so it can be concluded that the Capital Asset Pricing Model, Arbitration Pricing Theory, Three Factors Pricing Model, Four Factors Pricing Model, and Five Factors Pricing Model in this study has a difference in explaining excess return.

\subsection{Discussion}

4.2.1 The Effect of Capital Asset Pricing Model on excess stock returns (Y)

From this study it was found that the beta variable had an effect on excess return on shares. The amount of beta to excess stock return $(\mathrm{Y})$ is $34.7 \%$, meaning that the beta variable in explaining the variation of excess return is $34.7 \%$ while the rest is influenced by other factors outside the research model. Although the beta value is only $34.7 \%$, investors can still use beta as an indicator to consider stock returns that can be used as a basis for making decisions to invest. The CAPM only considers the risk free and risk market factors, where risk free is a risk free from SBI and the risk market is an indicator of the movement of the JCI, so that in the CAPM it is assumed that the high or low returns are caused only by these two factors. In fact, every investor has different behaviors and references in terms of assessing returns and whether or not an investment decision is feasible. The results of other studies supporting this research were carried out by Ezekiel Oseni and Razak Olawale Olanrewaju (2017); Zainul Kisman, Shintabelle Restiyanita M. (2015).
This means that each model in asset pricing in this study will give different results, this is due to the different variables used by each existing model. This is in accordance with the results of the research conducted, where each model gives different results.

\subsubsection{The Effect of Arbitration Pricing} Theory on excess stock returns (Y)

From this study it was found that inflation variable (X1), currency exchange rate (X2), Bank Indonesia interest rate (X3), money supply (X4), and gross domestic product (X5) have a joint effect on excess return on shares. The amount of inflation variable (X1), currency exchange rate (X2), Bank Indonesia interest rate (X3), money supply (X4), and gross domestic product (X5) for excess return stock (Y) is 0.552 or $55.2 \%$ while $44.2 \%$ is influenced by other factors outside the variables studied. This means that investors can use inflation values, currency exchange rates, Bank Indonesia interest rates, the money supply, gross domestic product as an indicator to consider stock returns that can be used as a basis for making decisions to invest. Overall the five macroeconomic factors used in this study are quite good, but there are still various other external factors which can also influence excess returns but are not included in this study, such as world oil prices, and gold prices. Therefore investors are expected before conducting their investment activities in addition to considering the fundamental factors must also consider external factors (macroeconomics), because these factors 
cannot be controlled by the company. The results of other studies supporting this research were conducted by Gusni and Suskim Riantani (2017); Gul and Khan (2013).

\subsubsection{The Effect of Three Factors Pricing} Model on excess stock returns (Y)

From this study it was found that market returns, small minus big (SMB), high minus low (HML) had a joint effect on excess stock returns. The magnitude of the effect of market return $\left(X_{1}\right)$, small minus big (SMB) $\left(\mathrm{X}_{2}\right)$, high minus low (HML) (X3) on excess stock returns (Y) is 0.772 or $77 \%$ while $23 \%$ is influenced by other factors outside the variables studied. This means that investors can use market return values, small minus big (SMB), high minus low as one indicator to consider stock excess returns, which can then be used as a basis for making decisions for their investments. The results of this study are in accordance with the research conducted by Susanti (2013) which states that simultaneously the entire Fama-French three factor variable is having a very large influence of $99.8 \%$. The existence of these influences together shows that the factors contained in the Fama French threefactor model together influence the size of stock returns.

In addition this is because SMB and HML in the company are considered to have a very important role for the sustainability of the company, so that the SMB and HML variables can explain the ability to generate returns for investors. The results of other studies supporting this study were carried out by Aldaarmi, et al. (2015) whose results show that the Fama and French 1993 model has more clear power and power in explaining changes in stock returns.

\subsubsection{The Effect of Four Factors Pricing Model on excess stock returns (Y)}

From this study it was found that market returns, small minus big (SMB), high minus low (HML), and Winner Minus Loser (WML) had a joint effect on excess stock returns. The magnitude of the effect of market returns, small minus big (SMB), high minus low (HML), and Winner Minus Loser (WML) is 0.790 or $79 \%$. This means that investors can use market return values, small minus big (SMB), high minus low (HML), and Winner Minus Loser (WML) as one indicator to consider stock excess returns which can then be used as a basis for making decisions for their investments. . The results of this study are consistent with the research conducted by Candika (2017); Trisnadewi (2012) who said that the Four Factors Pricing Model has a better performance in explaining returns. This is because there is an association between the momentums of stock performance in the past. Shares that are good performers (winners) or bad (losers) for three months to one year tend not to experience significant changes for the next period. Investors will tend to respond positively to stocks that have been shown to show good performance in the past which is indicated by the presence of buying activities in stocks that show that positive return, with the hope that the positive return will continue.

4.2.5 The Effect of Five Factors Pricing Model on excess stock returns ( $Y$ )

From this study it was found that market returns, small minus big (SMB), high minus low (HML), Robust Minus Weak (RMW) and Minus Aggressive Conservative (CMA) had an effect on the joint share return excess. The magnitude of the influence of market returns, small minus big (SMB), high minus low (HML), Robust Minus Weak (RMW) and Minus Aggressive Conservative (CMA) is 0.849 or $84.9 \%$. This means that investors can use market return values, small minus big (SMB), high minus low (HML), Robust Minus Weak (RMW) and Minus Aggressive Conservative (CMA) as indicators to consider excess stock returns which can then be used as a basis decision making for the investment. The results of this study in accordance with the research 
conducted by Fama \& French (2014), Chiah et al. (2015) and Wijaya et al. (2017) who stated that Five Factors asset pricing model which was introduced by Fama \& French had the best ability in explaining stock returns. This is because profitability and investment in the company are considered to have a very important role for the sustainability of the company, so investors see that the condition of the company that is able to generate profits and invest will create corporate value which will further increase returns for investors.

\subsubsection{The Best Model in Explaining Estimates against Excess Return}

Based on the results of the research conducted, the best model that can be used in assessing asset pricing models is the Five Factors Pricing Model, this is evidenced by the value of R 2 or R Square of $84.9 \%$, this value is greater than the value of R2 or R Square Capital Asset Pricing Models, Arbitration Pricing Theory, Three Factors Pricing Models, and Four Factors Pricing Models were $34.7 \%, \quad 55.2 \%, \quad 77.2 \%$ and $79 \%$ respectively. Looking at these results, the researchers assume that the more factors that are included to assess the return of a stock, the better.

Similarly, the Five Factors Pricing Model, with more internal variables compared to the Capital Asset Pricing Model and the Three Factors Pricing Model, and the Four Factors Pricing Model have proven that the model will be better, but in the Five Factors Pricing Model there are no external factors (macro) which in the previous study found that using five macro factors was able to provide a pretty good picture of returns, so the researchers concluded that if internal and external factors are used as indicators of research simultaneously, then allowing an assessment of asset pricing models would be more maximum.

\section{Coclussion}

Based on the test it can be concluded that the Capital Asset Pricing Model, Arbitration Pricing Theory, the Three Factors Pricing Model, the Four Factors Pricing Model, and the Five Factors Pricing Model have a significant effect on stock return (Y) on stocks in the 20122016 LQ45 Index. While for the most appropriate model in estimating returns based on testing, it can be concluded that the Five Factors Pricing Model is the best model in assessing asset pricing models compared to the Capital Asset Pricing Model, Arbitration Pricing Theory, Three Factors Pricing Models, and Four Factors Pricing Models in stocks. Shares on the LQ45 Index for the 2012-2016 period. Based on the results of the research, discussion and conclusions of the author, this study still contains several limitations and is expected to be refined in subsequent studies, such as expanding the research locus and extending the research period so that the results obtained will be more comprehensive.

\section{Reference}

Aldaarmi, dkk. 2015. Implement Fama And French And Capital Asset Pricing Models in Saudi Arabia Stock Market. The Journal Of Applied Business Reasearch May/June 2015 Volume 31, Number 3.

Bodie, Kane, \& Marcus. (2014). Manajemen Portoflio dan Investasi. Jakarta: Salemba Empat

Chandra, Antoni. 2014. Prediksi Return Saham : Perbandingan berdasarkan CAPM dan APT Pada Perusahaan Lq-45 di Bursa Efek Indonesia.

http://respository.wima.ac.id/1147

Candika, Yossy Imam.2017. Pengujuan Kekuatan Model Charhart Empat Faktor Terhadap Excess Return Saham Di Indonesia. The Indonesian Journal of Applied 
Business Volume 1, No. 1, April 2017

Darmadji, T.H.M Fakhrudin. 2012. Pasar Modal di Indonesia. Edisi Ketiga. Salemba Empat, Jakarta.

Darusman, Dery. 2012.Analisis Pengaruh Firm Size, Book To Market Ratio, Price Earning Ratio, dan Momentum Terhadap Return Portfolio Saham. Semarang : Universitas Diponegoro

Carhart, Mark M. 1997. On Persistence in Mutual Fund Performance. The Journal of Finance, Volume 52, Nomor 1, Hal 57-82.

Chiah, M., Chai, D., Zhong, A., 2015, A Better Model? An Empiricallnvestigation of FamaFrench Five-Factor Model in Australia, Proc,Monash Business School, Monash University.

Sheila Citra Wijaya, Werner Murhadi, Mudji Utami. 2017. Analisis Fama French Five Factor Model dan Three Factor Model Dalam Menjelaskan Return Portofolio Saham. Roundtable for Indonesian Entrepreneurship Educators (RIEE)-5.

Fauzyah. 2013. Pengaruh Pertumbuhan Ekonomi dan Tingkat SBDB Terhadap IHSG di Pasar Modal Indonesia. http://repository.usu.ac.id.

Fahmi, Irham. 2012. Pengantar Manajemen Keuangan. Bandung: Alfabeta

Fahmi, Irham. 2013. Analisis Laporan Keuangan. Bandung: Alfabeta.

Fama, E.F., dan K.R. French. 1993. "Common Risk Factors in the Returns on Stocks and Bonds". Journal of Finance. Vol. 48. Page.3-56.

Fama, E.F. dan French, K.R. 2014. A Five-Factor Asset Pricing Model, Journal of Financial Economics, 116.

Gul dan Khan (2013). An Application of Arbitrage Pricing Theory on KSE100 Index; A Study From Pakistan (2000-2005). IOSR Journal of Business and Management (IOSR-
JBM) e-ISSN: 2278-487X. Vol. 7, Issue 6 (Jan.- Feb. 2013), PP 7884.

Gusni dan Suskim Riantani. 2017. Penggunaan Arbitrase Pricing Theory Untuk Menganalisis Return Saham Syariah. Ultima Management Vol. 9 No. 1 Juni 2017

Irsyad, dkk. 2012. Studi Model Tiga Faktor Fama and French dan Return Saham. Semarang : Universitas Stikubank.

Isnurhadi. 2014. Analisis Model CAPM dalam Memprediksi Tingkat Return Saham Syariah dan Konvensional (Studi Kasus Saham di Bursa Efek Indonesia). Jurnal Ilmiah Manajemen Bisnis dan Terapan Tahun XI No. 1, April 2014.

Jogiyanto. (2015). Teori Portofolio dan Analisis Investasi. Yogyakarta: Universitas Gajah Mada.

Lemiyana. 2015. Analisis Model CAPM dan APT Dalam Memprediksi Tingkat Return Saham Syariah (Studi Kasus Saham di Jakarta Islamic Index). I-Finance Vol. 1, No, 1 Juli 2015.

Legiman, Fachreza Muhammad, et al. 2015. Faktor-faktor yang memoengaruhi return saham pada perusahaan agroindustry yang terdaftar di Bursa Efek Indonesia periode 2019-2012. Jurnal EMBA vol.3 No.3.

Maryaningsih, dkk. 2014. Pengaruh Infrastruktur Terhadap Pertumbuhan Ekonomi Indonesia. Buletin Ekonomi Moneter dan Perbankan, Volume 17, Nomor 1, Juli 2014

Oseni, Ezekieldan Razak Olawale Olanrewaju.2017. A Capital Asset Pricing Model's (CAPM's) Beta Estimation in the Presence of Normality and Non-normality Assumptions. International Journal of Finance and Banking Research Volume 3, Issue 3, June 2017, Pages: 44-52 
Susanti, Neneng. 2013. Pengujian Fama and French Three Factor Model PadaPerusahaan di Indonesia yang Sahamnya Terdapat di LQ 45 Tahun 2005-2009. Forum Keuangan \& Bisnis II, Th. 2013, ISBN: 978-602-17225-1-0.

Tandelilin, E. 2010. Portofolio Dan Investasi (Teori Dan Aplikasi). Edisi Pertama. KANISIUS.Yogyakarta.

Trisnadewi, Mariana. 2012. Analisis Pengaruh Risiko Pasar, Size, Book to Market, dan Momentum
Terhadap Return Saham. Skripsi Sarjana Fakultas Ekonomika dan Bisnis Universitas Diponegoro Semarang.

Zainul Kisman, Shintabelle Restiyanita M.2015. The Validity of Capital Asset Pricing Model (CAPM) and Arbitrage Pricing Theory (APT) in Predicting the Return of Stocks in Indonesia Stock Exchange 20082010. American Journal of Economics, Finance and Management Vol. 1, No. 3, 2015, pp. $184-189$

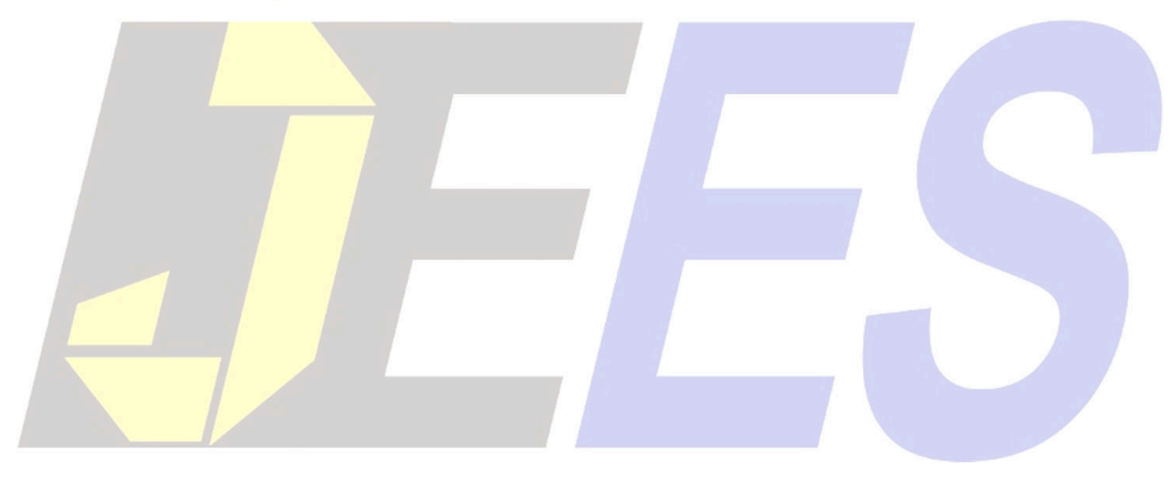

